This is the accepted version of an article published by Elsevier in Economic Modelling, Vol. 64, 638-645. Published version available from: https://doi.org/10.1016/j.econmod.2017.05.002

Accepted version made available from SOAS Research Online under CC-BY-NC-ND 4.0 International Licence from http://eprints.soas.ac.uk/24137/

The Importance of Being Remembered:

Prices for Cemetery Plots in the US

\author{
Paolo Canofari \\ Luiss School of European Political Economy \\ Rome, Italy \\ Giancarlo Marini \\ Dipartimento di Economia e Istituzioni, \\ Università di Roma Tor Vergata, \\ Rome, Italy

\section{Pasquale Scaramozzino} \\ School of Finance and Management, SOAS University of London, UK \\ and Dipartimento di Economia e Finanza, \\ Università di Roma Tor Vergata, \\ Rome, Italy
}

\title{
Acknowledgements
}

We are grateful to Fabrizio Adriani, Barbara Annicchiarico, Leonardo Becchetti, Luisa Corrado, Ciaran Driver, Alessandro Piergallini, Giovanni Vecchi, the Editor and two anonymous Referees for very helpful comments and suggestions. We remain responsible for any mistakes. 


\title{
The Importance of Being Remembered: \\ Prices for Cemetery Plots in the US
}

\begin{abstract}
The economic literature on end-of-life choices assumes that the utility of future generations is internalized by current generations through gifts and bequests. This explanation, however, cannot account for the decision to buy cemetery plots. This paper uses an original data set to look at the determinants of the grave prices in the US. "After-life" housing services are complements to "in-life" housing services. We find no evidence of selection bias associated with religious affiliation.

Keywords: Real estate, House prices, Grave prices

JEL classification: L85, Z13
\end{abstract}

\section{Introduction}

This paper addresses a largely overlooked issue in economics: the market for cemetery plots. The importance of the funeral housing market cannot be underestimated. In the US, funeral services are a $\$ 16$ billion a year industry, with about 25,000 businesses and with an average profit margin which increased from 5.8 percent in 2008 to 6.5 percent in 2013 (Barrett, 2013). The current death rate of $0.8 \%$ per annum implies an estimated need for 1.76 million burial or entombment spaces per year. According to the Final Arrangements Network, every year about 1.5 million people look for a cemetery property in USA. ${ }^{1}$ Nearly $30 \%$ of the US population already own some kind of cemetery property. Current demographic trends are likely further to increase pressure on burial spaces, which are expected to become scarce especially in urban areas (McManus, 2015; Tsang, 2015).

One possible reason for the neglect of the market for funeral services is the notion that a rational homo oeconomicus ought not to be concerned with this issue. Yet this view does not take into account the overwhelming historical importance attached to burial according to the majority of social and religious norms, at least in Western countries. In standard models in economics, individuals do not attach utility to what happens after their death unless they

\footnotetext{
${ }^{1}$ Private communication by Final Arrangements Network to the authors. The Network provides funeral and cremation services and lists plots for purchase and for sale across the USA.
} 
This is the accepted version of an article published by Elsevier in Economic Modelling, Vol. 64, 638-645. Published version available from: $h$ ttps://doi.org/10.1016/j.econmod.2017.05.002

Accepted version made available from SOAS Research Online under CC-BY-NC-ND 4.0 International Licence from http://eprints.soas.ac.uk/24137/

are linked to their descendants or to future generations through other-regarding preferences. Economics, in spite of its reputation as "the dismal science", tends to ignore the issue of death and burial. The infinitively-lived representative agent model is the standard workhorse in intertemporal economics and, even when death is allowed, the infinite-horizon paradigm can be restored by assuming that altruistic generations are linked by a perfect chain of gifts and bequests, possibly modified to allow for strategic interactions between generations as in the classic paper by Bernheim, Shleifer and Summers (1985).

It is however difficult to motivate the purchase of cemetery plots as a direct form of altruism towards one's children: rather, this can be justified by the desire to be remembered. A cemetery burial will make it easier to keep the memory of one's ancestors alive, and knowledge of this could generate a positive utility. Individuals could consider that their descendants will find comfort from visiting their grave. Visiting cemeteries and funerary homes and remembering one's ancestors transmit cultural and familial attachment across generations. $^{2}$

Other social science disciplines have also largely ignored burial practices and cemetery grounds. Exley (2004) argues that such scant attention may reflect a societal instinct for self-preservation, which may be related to the need to exorcise the deep anxieties associated with the fear of death (Becker, 1973; see also Solomon et al., 2015). Studies of the architectural and geographic aspects of cemeteries as "total landscapes" have also been very sparse: Francaviglia (1971) is one of the few examples.

Economic contributions to the field include Harrington and Krynski (2002) and Harrington (2007), who provide evidence on the lack of competition in the funeral services market, and Case and Menendez (2011), who examine funeral expenses by South African households. Hussein and Rugg (2003), Wickersham and Yehl (2013) and Longoria (2014) focus on the management of cemeteries, whilst Harrington and Treber (2013) look at the market for cemeteries and funeral establishments. In a recent paper, Faye and Channac (2016) analyse the main determinants of burial plot pricing in French cemeteries using a hedonic model.

This paper contributes to the literature by analysing the market for cemetery properties in the US, which is unregulated compared to other countries and thus approximates

\footnotetext{
${ }^{2} \mathrm{We}$ are very grateful to a referee for this suggestion.
} 
This is the accepted version of an article published by Elsevier in Economic Modelling, Vol. 64, 638-645. Published version available from: https://doi.org/10.1016/i.econmod.2017.05.002

Accepted version made available from SOAS Research Online under CC-BY-NC-ND 4.0 International Licence from http://eprints.soas.ac.uk/24137/

a competitive market. We make use a hitherto unutilised data set based on the asking prices listed by Grave Solutions, a company founded in 1996 which manages a large resale programme for cemetery properties. We collected the selling price offers for all US states in December 2010. In total, we obtained data on 10,674 advertisements. These include information on the cemetery name, city, state, property type, and the selling offer price. ${ }^{3} \mathrm{We}$ could also establish whether the transaction referred to a direct sale, or whether Grave Solutions was acting as a broker between a buyer and a seller. The latter transactions have been excluded from the analysis, which therefore only includes direct sales between parties.

In a relatively unregulated market like the US it is not uncommon to find advertisements of grave exchanges due to migration to a different State. This secondary market for graves offers a unique opportunity to carry out an empirical investigation of the market for funeral services. As a rule, funeral homes are not allowed to offer a discount from their general price list. ${ }^{4}$ Hence, the prices at which cemetery plots are put for sale by funeral homes may not be consistent with market clearing. However, the prices at which cemetery spaces are exchanged through a resale programme would reflect more closely the balance between demand and supply of funeral plots.

We have also collected data on house prices, in order to be able to compare them with grave prices. A data set on real estate selling offer prices has been constructed from Trulia Real Estates, which reports house prices by neighbourhood, city, county, and state. The information on house prices has been matched with the data on grave prices to investigate their comovements and determinants.

It could be argued that grave and housing prices are both closely related to the price of land (see for instance Harvey and Jowsey, 2004), and therefore it is important to account for the latter in order to establish whether house prices still have an influence on grave prices, once the price of land is controlled for. In order to address this potential criticism, we made use of data on land prices from the Lincoln Institute of Land Policy. Land prices are computed as the difference between the home value and the cost of building a new 1,800square foot one-story home. In addition to land prices, we also measured the regulatory

\footnotetext{
${ }^{3}$ The paper considers the asking prices because our implicit assumption is that they approximate prices at which cemetery plots are actually bought and sold. In this perspective they can be considered equilibrium price levels.

${ }^{4}$ Their prices are regulated by the Federal Trade Commission, which can impose penalties for violations of their rules (FTC, 2015).
} 
This is the accepted version of an article published by Elsevier in Economic Modelling, Vol. 64, 638-645. Published

version available from: $h$ ttps://doi.org/10.1016/j.econmod.2017.05.002

Accepted version made available from SOAS Research Online under CC-BY-NC-ND 4.0 International Licence from http://eprints.soas.ac.uk/24137/

environment for the housing market with the help of the Wharton Residential Land Use Regulatory Index developed by Gyourko, Saiz and Summers (2008). This indicator measures the stringency of land use control across over 2,000 jurisdictions in the US. ${ }^{5}$

We consider a simple demand and supply model where the services from both real estate and graves enter individuals' utility function, and derive testable propositions to analyse the relationship between housing when alive and after death. In the empirical analysis we control for a number of additional possible determinants of the housing price, such as demographic and religious variables, and for the potential endogeneity of house prices. We also carry out a sensitivity analysis to assess the robustness of our findings with respect to the intensity of religious affiliation.

The structure of the paper is as follows. Section 2 sets out a simple choice theoretic model for both conventional and funeral housing services. Section 3 describes the data used in the analysis. Section 4 presents and discusses our main empirical findings. Section 5 carries out a sensitivity analysis to establish the robustness of our results. Section 6 concludes.

\section{The market for housing services}

We consider a very simple model as a guide to the empirical analysis. Because of the crosssectional nature of our data, we would not be able to study the implications of intertemporal choice nor the possible strategic interactions among family members pertaining to the demand for funeral services. We therefore consider a lifetime utility function for the household, whose arguments are the consumption of after-life, or funeral housing services $h_{1}$, the consumption of in-life, or conventional, housing services $h_{2}$, and the consumption of a residual composite commodity $c$ :

$$
U\left(h_{1}, h_{2}, c ; \boldsymbol{x}_{D}\right)
$$

where $\boldsymbol{x}_{D}$ represents a vector associated with individual preferences, including religious beliefs and demographic characteristics, which capture heterogeneity across households. The

\footnotetext{
${ }^{5}$ The level of regulation for the use of land can have a relevant impact on house prices (Zhang et al., 2013).
} 
This is the accepted version of an article published by Elsevier in Economic Modelling, Vol. 64, 638-645. Published

version available from: $h$ ttps://doi.org/10.1016/j.econmod.2017.05.002

Accepted version made available from SOAS Research Online under CC-BY-NC-ND 4.0 International Licence from http://eprints.soas.ac.uk/24137/

utility function $U\left(h_{1}, h_{2}, c ; \boldsymbol{x}_{D}\right)$ is increasing in all its arguments and strictly quasi-concave. As explained in the introduction, the inclusion of the funeral housing services $h_{2}$ is motivated by the desire to be remembered after the end of one's life. The lifetime budget constraint takes the form:

$$
p_{1} h_{1}+p_{2} h_{2}+c \leq y
$$

where $y$ is lifetime income, $p_{1}$ and $p_{2}$ denote the prices of funeral housing services and of conventional housing services respectively, and where the price index for the residual consumption commodity has been normalized to one.

The Marshallian demand functions for the housing services $h_{1}$ and $h_{2}$ obtained from the maximization of the utility function (1) subject to the budget constraint (2) can be written as:

$$
h_{i}=g_{i}\left(y, p_{1}, p_{2} ; \boldsymbol{x}_{D}\right) \quad i=1,2
$$

The corresponding price elasticities are defined as:

$$
e_{i j}=\frac{\partial \operatorname{lng} g_{i}\left(y, p_{1}, p_{2} ; x_{D}\right)}{\partial \ln p_{j}} \quad i, j=1,2
$$

and the income elasticities as:

$$
e_{i}=\frac{\partial \operatorname{lng} g_{i}\left(y, p_{1}, p_{2} ; x_{D}\right)}{\partial \ln y} \quad i=1,2
$$

where $\ln$ denotes natural logarithm.

The relationships of complementarity and substitutability between housing services can be expressed in terms of their cross-price elasticity $e_{i j}, i \neq j$ (Deaton and Muellbauer, 1980). In particular, in-life and after-life housing services are complements if $e_{12}<0$ and substitutes if $e_{12}>0$. A housing service is a necessity if the income elasticity of its Marshallian demand function is less than one: $e_{i}<1$, and a luxury if $e_{i}>1$. Finally, a housing service can be defined an inferior good if the income elasticity of its Marshallian demand function is negative: $e_{i}<0$.

The housing services supply is described by the following function:

$$
h_{i}=f_{i}\left(p_{1}, p_{2}, p_{\ell} ; x_{S}\right) \quad i=1,2
$$


This is the accepted version of an article published by Elsevier in Economic Modelling, Vol. 64, 638-645. Published

version available from: $h$ ttps://doi.org/10.1016/j.econmod.2017.05.002

Accepted version made available from SOAS Research Online under CC-BY-NC-ND 4.0 International Licence from http://eprints.soas.ac.uk/24137/

where $p_{\ell}$ is the price of land and where $\boldsymbol{x}_{S}$ is a vector of supply-side variables, which capture spatial heterogeneity and which include regulations on land use. The prices of funeral services and of housing services, $p_{1}$ and $p_{2}$, are jointly determined by the system of equations (3) and (6). Hence, the price of housing services must be regarded as endogenous when looking at the determinants of the price of funeral services. The components of the vector $\boldsymbol{x}_{S}$ which are not included in $\boldsymbol{x}_{D}$, such as regulations on land use, would be suitable instruments for housing prices in the econometric estimations.

The model presented above allows us to study the variability across U.S. states of the prices of housing and funeral services as related to both the demand and the supply of these services. After controlling for endogeneity, a positive relationship between the prices of inlife and of after-life housing services can be interpreted as corresponding to conventional housing and funeral services being complementary commodities in the households' utility, whist a negative relationship would correspond to these services being substitute commodities for households.

\section{The data}

The original data set used in this paper has been constructed on the basis of 10,684 observations from Grave Solutions. ${ }^{6}$ This is a network that provides information on cemetery properties for sale offered by private parties, by cemeteries, and through brokerage services in the US. In order to obtain a sufficiently large sample, we collected all the advertisements of stocks for sale that were published in December 2010. All the data have been manually downloaded from the records reported in the website. The publicly available information includes the cemetery name, city, state, property type, selling offer price, number of spaces or of crypts, and whether Grave Solutions is acting as a broker in the transaction. The property is classified as a mausoleum if it is above ground and as a cemetery plot if it is below ground.

The main advantage of using Grave Solutions as our main data source is that this network supports a large resale programme for cemetery properties. In the USA, most funeral

\footnotetext{
${ }^{6}$ See the Data Appendix.
} 
This is the accepted version of an article published by Elsevier in Economic Modelling, Vol. 64, 638-645. Published version available from: https://doi.org/10.1016/i.econmod.2017.05.002

Accepted version made available from SOAS Research Online under CC-BY-NC-ND 4.0 International Licence from http://eprints.soas.ac.uk/24137/

homes cannot offer a discount from their general price list (FTC, 2015). As a consequence, the prices at which they sell their cemetery plots may involve rationing on the short side of the market, and therefore may not be fully consistent with market clearing. Since Grave Solutions specializes on the resale of cemetery spaces, however, the prices at which these spaces are offered are likely to be closer to the market clearing prices. Use of the offer price rather than the price at which graves are actually exchanged should not bias our statistical estimates, since there is no reason to believe that the bid-ask spread would be correlated to the control variables in the regressions.

The variable on grave prices has been obtained by dividing the price of the cemetery plot or mausoleum by the number of spaces. It is therefore a unit price per cemetery space. The average unit grave price is US\$ 2,261.941 and the median price is US\$ 1,900.00, with a standard deviation of US\$2,021.23. All the observations for which Grave Solutions is acting as a broker, and for which a transaction fee of $15 \%$ of the gross sale price is applied, have been excluded from the sample. Our analysis therefore only includes those observations which pertain to a transaction between a buyer and a seller.

In some of the main econometric investigations in this paper, grave prices have been averaged by state. Table 1 summarizes key descriptive statistics in 2010 for the main variables used in the analysis. ${ }^{7}$ The average personal income in the sample of states is about $\$ 34,875$. The average house price is $\$ 304,485$, whereas the average grave price is $\$ 1,960$. The highest grave price is observed in Hawaii with $\$ 3,807$, whilst the lowest is recorded in Maine with $\$ 700$. Hawaii also has the highest house price $(\$ 913,148)$ and land price $(\$ 483,730)$, as well as the highest land regulation index. The lowest house price is observed in Ohio $(\$ 170,887)$ and the lowest land price in Iowa $(\$ 7,095)$; Kansas is the least regulated country.

Table 1 also provides details of the proportion of population aged 65 or over, of the mortality rate, of the percentage of religious affiliation, of the cremation rate and of the urbanization rate. The urbanization rate is highest in California (95\%) and lowest in Maine (38.7\%). The cremation rate is highest in Nevada (73.0\%) and lowest in Mississippi (12.5\%).

The correlation coefficients between pairs of variables are shown in Table 2. Grave price, house price, personal income and land price are expressed in natural logs, which is the

\footnotetext{
${ }^{7}$ Please see the Data Appendix for a full description of all the variables used in the analysis and of their sources.
} 
This is the accepted version of an article published by Elsevier in Economic Modelling, Vol. 64, 638-645. Published version available from: $h$ ttps://doi.org/10.1016/j.econmod.2017.05.002

Accepted version made available from SOAS Research Online under CC-BY-NC-ND 4.0 International Licence from http://eprints.soas.ac.uk/24137/

format used in the regression equations. Some of the variables are strongly correlated across the states in the sample. In particular, the grave price is correlated both with the house price $(0.3290)$ and with the urbanization rate $(0.4856)$. Interestingly, the grave price is negatively correlated with the proportion of population over 65 years of age $(-0.3364)$. The land price is correlated with the house price (0.8270) and with personal income $(0.5179)$. The urbanization rate is also correlated with the house price $(0.6032)$, land price $(0.5106)$ and personal income (0.6329). The cremation rate is correlated with both house price (0.5029) and land price (0.5148), but not with the grave price (the correlation coefficient is only 0.1699 ). The Wharton land regulation index of Gyourko, Saiz and Summers (2008) is highly correlated with both house price $(0.7765)$ and land price $(0.7701)$, but not with grave price $(0.1853)$, which suggests that it could constitute a valid instrument for the endogenous house price in the equation for the grave price.

\section{Empirical findings}

\subsection{Grave prices}

Our data set contains information on over 10,000 observations on grave prices. Unfortunately it is not possible to obtain information on the individuals or on the households that purchased the cemetery plots. We cannot therefore match grave prices with the individual characteristics of buyers. It is however possible to match the grave price information with city- and statewide variables, and this provides us with the means to explore some potential determinants of these prices.

Table 3 presents the results of OLS cross-section regressions of the log of individual grave prices on a number of city- and state-level variables. The standard errors reported in the table are clustered by city. ${ }^{8}$ Column (a) indicates that grave prices are positively related to average house prices, whilst column (b) appears to show that they are positively but not significantly related to average personal income. When both variables are included in column (c), they are both statistically significant. Interestingly, however, personal income now has a negative sign. The average land price is not significant when added to the regression in

\footnotetext{
${ }^{8}$ See the Data Appendix for a full list of the 108 cities included in our analysis.
} 
This is the accepted version of an article published by Elsevier in Economic Modelling, Vol. 64, 638-645. Published

version available from: $h$ ttps://doi.org/10.1016/j.econmod.2017.05.002

Accepted version made available from SOAS Research Online under CC-BY-NC-ND 4.0 International Licence from http://eprints.soas.ac.uk/24137/

column (d), whereas the urbanization rate has a significant and positive sign as expected. The cremation rate and the proportion of population in the state that declare a religious affiliation do not contribute additional explanatory power to the OLS regressions when included in column (e). Column (f) is a parsimonious version of column (e): house prices and personal income still have a positive and a negative coefficient respectively, and both the urbanization rate and the cremation rate are statistically significant and with the expected signs.

Columns (g) and (h) display instrumental variables estimates with house price as an endogenous variable. The Wooldridge (1995) $F$ score endogeneity test in column (g) strongly rejects the null hypothesis that house prices are exogenous. The Kleibergen-Paap (2006) LM test for underidentification rejects the null hypothesis that the matrix of reduced form coefficients on the excluded instruments has less than full rank, and therefore the model is identified. The Kleibergen-Paap (2006) Wald test also rejects the hypothesis that the instruments are only weakly correlated with the endogenous regressor. The Hansen $J$ test for overidentification is however statistically significant, indicating that the instruments may not be orthogonal to the regression disturbances. The sign of the estimated coefficients remains unchanged relative to OLS, but the size of the coefficient on house price is now much larger. There is therefore no evidence that the effect of house prices on the price of graves is due to endogeneity. On the contrary, OLS understates rather than overstates the effect of house prices. Personal income is negative and significant, but so is land price which is puzzling as one would expect a positive effect on grave prices. The urbanization rate and the cremation rate however now cease to be significant. Religious affiliation remains statistically insignificant.

Column (h) presents a parsimonious version of $(\mathrm{g})$, with only the significant variables included in the regression. The estimated equation passes all the diagnostic tests, including now also the Hansen $J$ test on the orthogonality of the set of instruments.

These results suggest that the prices for graves tend to move in the same direction as prices for conventional housing. A possible interpretation of this result is that both types of housing services act as complements in the utility of households. An increased demand for housing would also be associated with an increase in the demand for funeral housing, and therefore also with a higher price level for grave spaces. 
This is the accepted version of an article published by Elsevier in Economic Modelling, Vol. 64, 638-645. Published

version available from: $h$ ttps://doi.org/10.1016/j.econmod.2017.05.002

Accepted version made available from SOAS Research Online under CC-BY-NC-ND 4.0 International Licence from http://eprints.soas.ac.uk/24137/

The negative coefficient on personal income can be interpreted as indicating that services from funeral homes are considered an inferior good in the household's utility, since their demand declines as income increases. A possible explanation for this negative sign is that households may plan to invest up to a fixed amount on cemetery plots. As their income increases, the share of money invested in them would therefore decline. ${ }^{9}$

\subsection{Grave prices by state}

It is important to establish whether the main results from Table 3 also hold when both the dependent variable and the control variables pertain to the same level of aggregation, and are therefore coherent in terms of their geographical scope. Table 4 thus shows the results of OLS and IV cross-section regressions over 39 US states of the average prices of cemetery plots.

The main results in Table 4 are consistent with those of Table 3. Columns (a)-(e) present OLS regressions and columns (f)-(g) estimates by instrumental variables. Columns (e) and (f) are parsimonious specifications of the OLS regression and of the IV regression respectively. House prices are positively related and personal income is negatively related to grave prices. In contrast to the individual level regressions, however, land price is statistically insignificant, whereas the urbanization rate is always positive and significant. The mortality rate and the cremation rate also become significant at the state level when they are both included in the regression. The cremation rate is here included as a dummy, which takes the value of 1 when the cremation rate in the state is greater than the median $(33.5 \%)$. This dummy has a negative sign as expected, since cremation is an alternative to burial. The negative sign of the mortality rate represents however a puzzle, since an increased values of this rate can be expected to be associated with increased demand for burial places. Religious affiliation is not statistically significant when included in the regression in columns (d) and (f). Other demographic variables such as the proportion of population aged 65 or over are insignificant when included in the regressions.

The coefficients in the IV estimates of column (g) have the same sign and are very similar in size to the OLS estimates of column (e). At the state level, however, we cannot

\footnotetext{
${ }^{9}$ We owe this explanation to a referee.
} 
This is the accepted version of an article published by Elsevier in Economic Modelling, Vol. 64, 638-645. Published

version available from: $h$ ttps://doi.org/10.1016/j.econmod.2017.05.002

Accepted version made available from SOAS Research Online under CC-BY-NC-ND 4.0 International Licence from http://eprints.soas.ac.uk/24137/

reject the null hypothesis that the house price is exogenous. The diagnostic tests confirm that the model is identified and does not suffer from weak instruments. The test of overidentifying restrictions for the IV estimates is only marginally rejected at $10 \%$ significance level $(p=$ 0.0996).

The findings at state level confirm that cemetery plots and housing services can be regarded as complements, and that funeral services are an inferior good in the utility of households. The cremation rate has a negative coefficient as expected. The negative coefficient on the mortality rate is a puzzle though, as one would expect this variable to have a positive effect on the demand for grave spaces. The positive coefficient on the urbanization rate in both the OLS and IV regressions can be explained by the greater competition for land use in urban areas, consistent with standard models in land economics (see for instance Harvey and Jowsey, 2004, and Feng and Wu, 2015).

\section{Sensitivity analysis: the role of religious affiliation}

A potentially critical issue with our analysis is that the demand for cemetery plots may reflect a form of self-selection. Individuals may choose either to be buried or to be cremated on the basis of their religious beliefs. Funeral rituals associated with burial usually follow strict normative prescriptions. In our regression analysis, religious affiliation has no explanatory power on the price of grave prices either at the individual or at the state level. Religiosity is however highly significant in equations for the cremation rate. The estimated regression at the state level gives:

$$
\text { Cremation rate }=2.596-0.026 \times \text { Religious affiliation }
$$

$$
\text { (0.240) (0.003) }
$$

(heteroskedasticity-robust standard errors in brackets): grave price, house price, personal income, land price and urbanisation rate are not statistically significant. Very similar results are obtained at the individual level. ${ }^{10}$ Religiosity can affect the choice of being buried or cremated, and could therefore act as a confounding factor in the determination of grave

\footnotetext{
${ }^{10}$ The estimated coefficient on religious affiliation in individual regression is -0.023 (s.e. 0.002 ). Full results are available from the authors upon requests.
} 
This is the accepted version of an article published by Elsevier in Economic Modelling, Vol. 64, 638-645. Published

version available from: $h$ ttps://doi.org/10.1016/j.econmod.2017.05.002

Accepted version made available from SOAS Research Online under CC-BY-NC-ND 4.0 International Licence from http://eprints.soas.ac.uk/24137/

prices. The decision to be either buried or cremated is not random, but depends on religious beliefs. There could therefore be a potential selection bias which could affect the estimates of the effects of religiosity on grave prices.

The present section explores this possibility by carrying out a sensitivity analysis where religious affiliation can act as a confounding factor for the price of cemetery plots. We are thus able to establish whether our results are robust to the intensity of religious beliefs. Our analysis is based on the Conditional Independence Assumption (CIA), which can be less restrictive than the orthogonality assumptions required for regression analysis since it allows for more general non-linear effects of the covariates on the dependent variable. The unconfoundedness assumption cannot be tested directly, but a general methodology to conduct indirect tests is discussed in Imbens (2004). Blattman and Annan (2010) examine the impact of abduction and forced combat recruitment on human capital and labour market outcomes of Ugandan youth. Becchetti, Fiaschetti and Marini (2014) implement this approach to rule out that the more cooperative behaviour of bridge players vis $\grave{a}$ vis poker players can be explained by initial self-selection.

We examine the robustness of our results on grave prices with respect to religious beliefs by implementing a sensitivity analysis based on the procedure illustrated by Nannicini (2007) and Ichino, Mealli and Nannicini (2008), which extends Rosenbaum and Rubin (1983) and Rosenbaum (1987). The approach by Nannicini and by Ichino et al. simulates a potential confounder in order to establish the robustness of the treatment effects with respect to deviations from the Conditional Independence Assumption (CIA). The average treatment effect on the treated (ATT) is usually defined as:

$$
E\left(Y_{1}-Y_{0} \mid T=1\right)=E\left(Y_{1} \mid T=1\right)-E\left(Y_{0} \mid T=1\right)
$$

where $Y_{1}$ is the outcome if the variable if exposed to treatment: $T=1$, and $Y_{0}$ is the outcome if the variable is not exposed to treatment: $T=0$. The counter-factual nature of the ATT effect can be seen by considering that $E\left(Y_{0} \mid T=1\right)$ cannot be observed. Estimation of ATT usually requires the Conditional Independence Assumption, which maintains that the potential outcome in the absence of treatment is orthogonal to treatment assignment conditional on a set of covariates $W$ :

$$
Y_{0} \perp T \mid W
$$


This is the accepted version of an article published by Elsevier in Economic Modelling, Vol. 64, 638-645. Published

version available from: $h$ ttps://doi.org/10.1016/j.econmod.2017.05.002

Accepted version made available from SOAS Research Online under CC-BY-NC-ND 4.0 International Licence from http://eprints.soas.ac.uk/24137/

In the context of the analysis of this paper, the outcome $Y$ is the price of the grave and $T$ represents either burial in a cemetery plot $(T=1)$ or cremation $(T=0)$. The vector $W$ is the set of conditioning variables used as regressors in the equation. In our application, ATT would thus measure the expected percentage difference in grave prices when a cemetery plot is chosen instead of cremation.

CIA is an identifying assumption and as such it is untestable. It is however possible to assess the robustness of the results with respect to departures from the assumption. The sensitivity analysis proposed by Nannicini et al. is based on a confounding variable $U$ such that CIA holds conditional on both $W$ and $U$ :

$$
Y_{0} \perp T \mid(W, U)
$$

For the analysis of this paper, $U$ is a measure of the intensity of religious beliefs held by households. The robustness of CIA can then be established by simulating the potential confounder $U$ in the data. Let $Y$ denote the potential outcome for a given unit: $Y=T \cdot Y_{1}+$ $(1-T) \cdot Y_{0}$. When $Y_{1}, Y_{0}$ and $U$ are all binary, the distribution of the confounding variable $U$ is described by the following parameters:

$$
p_{i j}=\operatorname{Pr}(U=1 \mid T=i, Y=j)=\operatorname{Pr}(U=1 \mid T=i, Y=j, W)
$$

where $i, j \in\{0,1\}$. A confounder is potentially "dangerous" when

$$
\begin{aligned}
& \operatorname{Pr}\left(Y_{0}=1 \mid T, W, U\right) \neq \operatorname{Pr}\left(Y_{0}=1 \mid T, W\right) \\
& \operatorname{Pr}(T=1 \mid W, U) \neq \operatorname{Pr}(T=1 \mid W)
\end{aligned}
$$

Ichino et al. (2007) show that it is possible to simulate a "dangerous" confounder if the following restrictions hold:

$$
\begin{aligned}
& p_{01}>p_{00} \Rightarrow \operatorname{Pr}\left(Y_{0}=1 \mid T=0, U=1, W\right)>\operatorname{Pr}\left(Y_{0}=0 \mid T=0, U=1, W\right) \\
& p_{1 .}>p_{0} . \Rightarrow \operatorname{Pr}(T=1 \mid U=1, W)>\operatorname{Pr}(T=1 \mid U=0, W)
\end{aligned}
$$

The restrictions (13) and (14) can thus be expressed in terms of the following assumptions:

$$
\begin{aligned}
& d=p_{01}-p_{00}>0 \\
& s=p_{1} \cdot-p_{0} .>0
\end{aligned}
$$


This is the accepted version of an article published by Elsevier in Economic Modelling, Vol. 64, 638-645. Published

version available from: https://doi.org/10.1016/i.econmod.2017.05.002

Accepted version made available from SOAS Research Online under CC-BY-NC-ND 4.0 International Licence from http://eprints.soas.ac.uk/24137/

Assumption (16) requires that the confounder $U$ has a positive effect on the outcome $Y$, conditional on $W$. Assumption (17) requires that the confounder $U$ has a positive effect on the treatment $T$, conditional on $W$. The magnitude of these effects is then estimated by logit or probit regressions. For the analysis of the present paper, assumption (16) requires that religiosity has a positive effect on grave prices, and assumption (17) that religiosity has a positive effect on the probability of choosing to be buried in a cemetery plot rather than to be cremated.

Table 5 presents the results of sensitivity analysis with respect to religious affiliation. Continuous variables have been transformed into binary form by setting them equal to 1 if they are greater than or equal to the median and as equal to 0 if they are smaller than the median. The outcome variable is therefore equal to unity if the price is above the median. The baseline estimate average treatment effect on the treated (ATT) on the first row is estimated at 0.066 and is not statistically significant. This measures the expected percentage difference in grave prices when a cemetery plot is chosen instead of cremation (equation (8)). We then proceeded to calibrate the distribution of confounders by considering a range of possible values for the probabilities $p_{i j}$ in (10): $p_{11}$ denotes the probability that religiosity is high, conditional on the choice of a cemetery plot and on a high grave price; $p_{10}$ denotes the probability that religiosity is high, conditional on the choice of a cemetery plot and on a low grave price; $p_{01}$ denotes the probability that religiosity is low, conditional on the choice of cremation and on a high grave price; $p_{00}$ denotes the probability that religiosity is low, conditional on the choice of cremation and on a low grave price. The parameter $d$ measures the effect of high religious intensity on the probability of a high grave price, conditional on cremation being chosen, whereas $s$ measures the effect of high religious intensity on the probability that a cemetery plot is chosen. Both effects are assumed to be positive.

The results in Table 5 show that religiosity has the potential for affecting the price of graves. In the case of calibration (a), the effect on estimated ATT is a decline from 0.066 to 0.047 , i.e. a reduction by $28.8 \%$. This can be interpreted as the expected decline in the difference in grave prices when a cemetery plot is chosen instead of cremation. Under calibration (b) the reduction in estimated ATT is $53 \%$, under (c) it is $48.5 \%$, and under (d) the estimated ATT declines by $83.3 \%$. The bootstrapped standard errors remain large however, and therefore these declines are not statistically significant. Whilst religiosity could play a role in affecting the estimated price of cemetery plots when these are chosen instead of 
This is the accepted version of an article published by Elsevier in Economic Modelling, Vol. 64, 638-645. Published

version available from: $h$ ttps://doi.org/10.1016/j.econmod.2017.05.002

Accepted version made available from SOAS Research Online under CC-BY-NC-ND 4.0 International Licence from http://eprints.soas.ac.uk/24137/

cremation, its effect tends to decline with religious affiliation and is never statistical significant. The sensitivity analysis therefore does not support the existence of a potential selection bias which could affect the estimates of effects of religious intensity on grave prices.

\section{Conclusions}

The market for cemetery properties in the US is an important one, with one and a half million properties per year needed to accommodate the deceased. About one third of Americans already own a property whilst alive, and most others rely on their relatives to provide for it when the need arises. Yet, the economic aspects of this market have almost never been studied before.

Our study shows that there is a link between the demand for cemetery plots and the demand for conventional housing. The prices of graves and of houses are related at all levels of aggregation. Their services can thus be regarded as complements in the households' utility function. A possible justification for including the services from cemetery plots in the utility function lies in the desire to be remembered, and in the knowledge that their descendants will find it easier to keep their loved ones in their memory by visiting their grave.

Grave prices are also found to decrease as the level of income increases. A possible explanation is that services from funeral homes can be considered as an inferior good in the household's utility, since their demand declines as income increases. The intuition behind this is that the share of income invested in funeral services declines for higher income levels.

A large number of issues remain to be explored. It would be useful to have data on grave prices over several time periods, so that it would be possible to introduce a time dimension to the analysis. It would also be useful to be able to match data on grave prices to panel data on households, so that it would become possible to analyse the purchase of burial plots as part of an intertemporal planning decision which includes other investment in real estate as well as financial investment. 
This is the accepted version of an article published by Elsevier in Economic Modelling, Vol. 64, 638-645. Published

version available from: $h$ ttps://doi.org/10.1016/j.econmod.2017.05.002

Accepted version made available from SOAS Research Online under CC-BY-NC-ND 4.0 International Licence from http://eprints.soas.ac.uk/24137/

The questions posed above cannot be answered by the data set used in this paper, but it is our belief that these are important issues which deserve to be addressed by economists. The urgency of the issue is made apparent by the current inadequate provision of burial spaces in many parts of the world (McManus, 2015), which is bound to lead to increasing attention to the economic and financial aspects of family planning for funeral services.

\section{References}

Barrett, P.M., 2013. Is Funeral Home Chain SCI's Growth Coming at the Expense of Mourners? Bloomberg Businessweek, 24 October.

Becchetti, L., Fiaschetti, M., Marini, G., 2014. Card Games and Economic Behavior. Games and Economic Behavior 88 (C), 112-129.

Becker, E., 1973. The Denial of Death. Simon \& Schuster, New York.

Bernheim, B.D., Shleifer A., Summers L.H., 1985. The Strategic Bequest Motive. Journal of Political Economy 93 (6), 1045-1076.

Blattman, C., Annan J., 2010. The Consequences of Child Soldiering. The Review of Economics and Statistics 92 (4), 882-898.

Case, A., Menendez A., 2011. Requiescat in Pace? The Consequences of High Priced Funerals in South Africa. Chapter 11 in D. A. Wise (ed.), Explorations in the Economics of Aging, National Bureau of Economic Research, Inc. 351-373.

Deaton, A., Muellbauer, J., 1980. Economics and Consumer Behaviour. Cambridge University Press, Cambridge.

Exley, C., 2004. Review Article: The Sociology of Dying, Death and Bereavement. Sociology of Health and Illness 26 (1), 110-122.

Faye, B., Channac, F., 2016. A Hedonic Approach to Burial Plot Value in French Cemeteries. Urban Studies, forthcoming.

Francaviglia, R. V., 1971. The Cemetery as an Evolving Cultural Landscape. Annals of the Association of American Geographers 61 (3), 501-509. 
This is the accepted version of an article published by Elsevier in Economic Modelling, Vol. 64, 638-645. Published

version available from: $h$ ttps://doi.org/10.1016/j.econmod.2017.05.002

Accepted version made available from SOAS Research Online under CC-BY-NC-ND 4.0 International Licence from http://eprints.soas.ac.uk/24137/

Feng, Q., Wu., G. L., 2015. Bubble or Riddle? An Asset-Pricing Approach Valuation on China’s Housing Market. Economic Modelling 46, 376-383.

FTC, 2015. Complying with the Funeral Rule, Federal Trade Commission, April.

Gyourko, J., Saiz, A., Summers, A., 2008. A New Measure of the Local Regulatory Environment for Housing Markets: The Wharton Residential Land Use Regulatory Index. Urban Studies 45 (3), 693-729.

Harrington, D. E., 2007. Preserving Funeral Markets with Ready-to-Embalm Laws. Journal of Economic Perspectives 21 (4), 201-216.

Harrington, D. E., Krynski, K. J., 2002. The Effect of State Funeral Regulations on Cremation Rates: Testing for Demand Inducement in Funeral Markets. Journal of Law and Economics 45 (1), 199-225.

Harrington, D. E., Treber, J., 2013. Cemeteries and Mortuaries: Better Together or Apart? Regulation. Winter (2012-2013), 40-47.

Harvey, J., Jowsey, E., 2004. Urban Land Economics, $6^{\text {th }}$ edition, Palgrave Macmillan, New York.

Hussein, I., Rugg J., 2003. Managing London's Dead: A Case of Strategic Policy Failure. Mortality 18 (2), 209-221.

Ichino, A., Mealli, F., Nannicini, T., 2008. From Temporary Help Jobs to Permanent Employment: What Can We Learn from Matching Estimators and Their Sensitivity? Journal of Applied Econometrics 23 (3), 305-327.

Imbens, G. W., 2004. Nonparametric Estimation of Average Treatment Effects under Exogeneity: A Review. The Review of Economics and Statistics 86 (1), 4-29.

Kleibergen, F., Paap, R., 2006. Generalized Reduced Rank Tests Using the Singular Value Decomposition. Journal of Econometrics 133 (1), 97-126.

Longoria, T., 2014. Are We All Equal at Death? Death Competence in Municipal Cemetery Management. Death Studies 38 (6), 355-364.

McManus, J., 2015. The World is Running Out of Burial Space. BBC News Online, March $13^{\text {th }}$ (http://www.bbc.co.uk/news/uk-31837964).

Nannicini, T., 2007. A Simulation-Based Sensitivity Analysis for Matching Estimators. Stata Journal 7, 334-350.

Rosenbaum, P., 1987. Sensitivity Analysis to Certain Permutation Inferences in Matched Observational Studies. Biometrika 74 (1), 13-26. 
This is the accepted version of an article published by Elsevier in Economic Modelling, Vol. 64, 638-645. Published

version available from: https://doi.org/10.1016/j.econmod.2017.05.002

Accepted version made available from SOAS Research Online under CC-BY-NC-ND 4.0 International Licence from http://eprints.soas.ac.uk/24137/

Rosenbaum, P., Rubin, D., 1983. Assessing Sensitivity to an Unobserved Binary Covariate in an Observational Study with Binary Outcome. Journal of the Royal Statistical Society, Series B 45, 212-218.

Solomon, S., Greenberg, J., T. Pyszczynski, T., 2015. The Worm at the Core. On the Role of Death in Life, Allen Lane.

Tsang, A., 2015. Hong Kong Grave Shortage Leaves Dead in Limbo. Financial Times, March $8^{\text {th }}$.

Wickersham, M.E., Yehl, R., 2013. Public Cemetery: Meeting New Challenges in a Time of Change. Public Manager 42 (4), 62-65.

Wooldridge, J.M., 1995. Score Diagnostics for Linear Models Estimated by Two Stage Least Squares. In G. S. Maddala, P. C. B. Phillips, and T. N. Srinivasan (eds.), Advances in Econometrics and Quantitative Economics: Essays in Honor of Professor C. R. Rao, Oxford, Blackwell, 66-87.

Zhang, D., Cheng, W., Ng, Y. L., 2013. Increasing Returns, Land Use Controls and Housing Prices in China. Economic Modelling 31, 789-795. 
This is the accepted version of an article published by Elsevier in Economic Modelling, Vol. 64, 638-645. Published

version available from: $\mathrm{https}$ ///doi.org/10.1016/i.econmod.2017.05.002

Accepted version made available from SOAS Research Online under CC-BY-NC-ND 4.0 International Licence from http://eprints.soas.ac.uk/24137/

\section{Data Appendix.}

Variables and data sources.

Grave price: Unit price of cemetery plot (below ground) or of mausoleum (above ground), obtained by dividing the price of the plot or of the mausoleum by the number of spaces.

Source: Grave Solutions.

(http://www.gravesolutions.com/Default.asp)

House price: Price of homes for sale.

Source: Trulia Real Estate.

(http://www.trulia.com/home prices/)

Land price (States): Home value minus the cost to build a new 1800-square foot 1-story home.

Source: Lincoln Institute of Land Policy.

(https://www.lincolninst.edu/subcenters/land-values/land-prices-by-state.asp)

Land price (Metro Areas): Home value minus the cost to build a new 1800-square foot 1story home for each of the 46 large metropolitan areas in the United States.

Source: Lincoln Institute of Land Policy

(https://www.lincolninst.edu/subcenters/land-values/metro-area-land-prices.asp)

Personal income: Total disposable income in current US\$ divided by mid-year population. Source: U.S. Department of Commerce, Bureau of Economic Analysis.

(http://www.bea.gov/)

Population $>65$ : Total population aged 65 years and over divided by total population.

Source: U.S. Department of Commerce, United States Census Bureau.

(http://www.census.gov/popest/)

Urbanization rate: Urban Population as a Percentage of the Total Population by U.S. State.

Source: U.S. Census Bureau

(https://www.census.gov/geo/reference/ua/urban-rural-2010.html)

Land regulation index: Wharton Residential Land Use Regulatory Index

Source: Gyourko, Saiz and Summers (2008).

(http://real.wharton.upenn.edu/ gyourko/landusesurvey.html)

Religious affiliation: Percentages of each state's population that affiliates with any religion.

Source: The Pew Forum on Religion and Public Life, Religious Landscape Survey.

(http://religions.pewforum.org/maps\#) 
Cremation rate: Percentage of deceased persons who are cremated.

Source: Cremation Association of North America.

(http://www.cremationassociation.org/)

Population density: Number of people per square mile.

Source: U.S. Department of Commerce, United States Census Bureau.

(http://2010.census.gov/2010census/data/apportionment-dens-text.php)

List of states included in the analysis (39).

Alabama, Arizona, Arkansas, California, Colorado, Connecticut, Delaware, Florida, Georgia, Hawaii, Idaho, Illinois, Indiana, Iowa, Kansas, Kentucky, Louisiana, Maine, Maryland, Massachusetts, Michigan, Minnesota, Mississippi, Missouri, Nebraska, Nevada, New York, North Carolina, North Dakota, Ohio, Oklahoma, Oregon, Pennsylvania, South Carolina, Tennessee, Texas, Virginia, Washington, West Virginia.

List of cities (108).

Adelphi, MD; Akron, OH; Alexandria, VA; Allentown, PA; Arlington, TX; Atlanta, GA; Augusta, GA; Aurora, CO; Austin, TX; Baltimore, MD; Battle Creek, MI; Bellevue, WA; Bethlehem, PA; Birmingham, AL; Bradenton, FL; Canton, OH; Charleston, SC; Charleston, WV; Charlotte, NC; Chattanooga, TN; Chicago, IL; Cincinnati, OH; Clearwater, FL; Cleveland, OH; Colorado Springs, CO; Columbia, SC; Columbus, OH; Dallas, TX; Dayton, OH; Denver, CO; Des Moines, IA; Detroit, MI; Durham, NC; Evansville, IN; Fort Myers, FL; Fort Worth, TX; Fresno, CA; Gastonia, NC; Glendale, AZ; Glendale, CA; Grand Rapids, MI; Greeley, CO; Greensboro, NC; Greenville, SC; High Point, NC; Hoover, AL; Houston, TX; Indianapolis, IN; Jackson, MI; Jacksonville, FL; Kalamazoo, MI; Knoxville, TN; Lansing, MI; Las Vegas, NV; Lexington, KY; Little Rock, AR; Livonia, MI; Los Angeles, CA; Louisville, KY; Medford, OR; Memphis, TN; Mesa, AZ; Metairie, LA; Miami, FL; Minneapolis, MN; Mobile, AL; Montgomery, AL; Morgantown, WV; Murfreesboro, TN; Nashville, TN; New Orleans, LA; Norfolk, VA; North Charleston, SC; Ocala, FL; Oklahoma City, OK; Omaha, NE; Orlando, FL; Pensacola, FL; Peoria, IL; Philadelphia, PA; Phoenix, AZ; Pittsburgh, PA; Pompano Beach, FL; Portland, OR; Raleigh, NC; Richmond, VA; Rochester, MI; Rockford, IL; Sacramento, CA; Saginaw, MI; Salem, VA; San Antonio, TX; San Diego, CA; Sarasota, FL; Savannah, GA; Seattle, WA; Spokane, WA; St. Petersburg, FL; Summerville, SC; Tacoma, WA; Tampa, FL; Toledo, OH; Tucson, AZ; Tulsa, OK; Virginia Beach, VA; Washington, DC; West Des Moines, IA; Wilmington, DE. 
This is the accepted version of an article published by Elsevier in Economic Modelling, Vol. 64, 638-645. Published version available from: https://doi.org/10.1016/i.econmod.2017.05.002 Accepted version made available from SOAS Research Online under CC-BY-NC-ND 4.0 International Licence from http://eprints.soas.ac.uk/24137/

Figure 1. Grave prices by state.

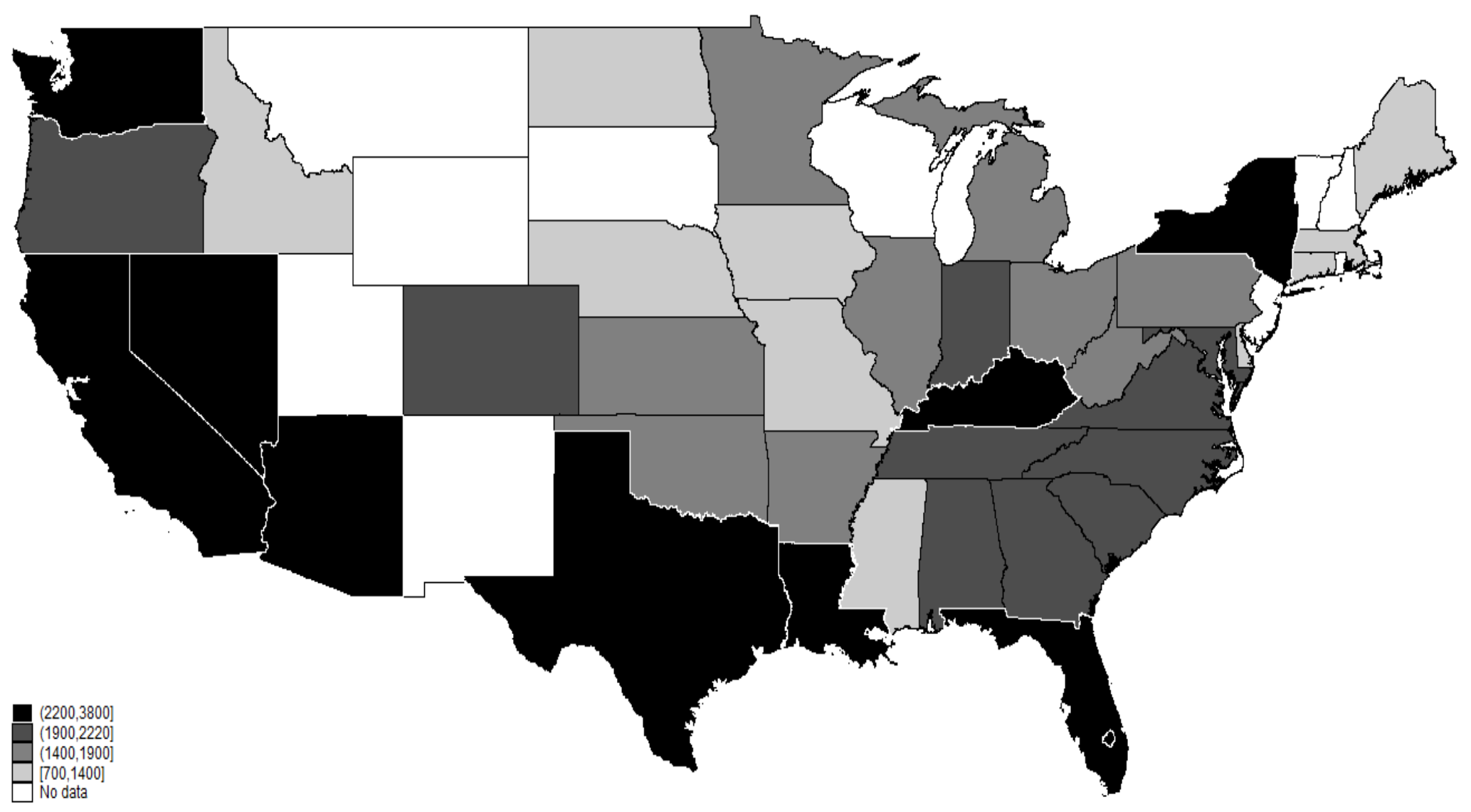


This is the accepted version of an article published by Elsevier in Economic Modelling, Vol. 64, 638-645. Published version available from: https://doi.org/10.1016/i.econmod.2017.05.002

Accepted version made available from SOAS Research Online under CC-BY-NC-ND 4.0 International Licence from http://eprints.soas.ac.uk/24137/

Table 1. Descriptive statistics.

\begin{tabular}{|l|ccccc|}
\hline Variable & Mean & Median & $\begin{array}{c}\text { Standard } \\
\text { Deviation }\end{array}$ & Min & Max \\
\hline Grave price & 1,960 & 1,948 & 716 & 700 & 3,807 \\
House price & 304,485 & 260,377 & 158,893 & 170,887 & 913,148 \\
Lersonal income & 34,875 & 34,385 & 4,441 & 28,387 & 47,797 \\
Urbanization rate & 61,614 & 27,113 & 90,995 & 7,095 & 483,730 \\
Population density & 0.747 & 0.746 & 0.137 & 0.387 & 0.950 \\
Population $>$ 65 & 183.064 & 104.9 & 193.933 & 9.7 & 839.4 \\
Mortality rate & 0.132 & 0.133 & 0.015 & 0.101 & 0.174 \\
Cremation rate & 0.270 & 0.163 & 0.284 & 0.018 & 1.434 \\
Religious affiliation & 0.384 & 0.335 & 0.164 & 0.125 & 0.730 \\
Land regulation index & -0.156 & -0.347 & 0.769 & -1.118 & 2.304 \\
\hline
\end{tabular}

Note: Religious affiliation is not available for Hawaii and Mississippi. 


\section{Table 2. Correlation coefficients.}

\begin{tabular}{|c|c|c|c|c|c|c|c|c|c|c|c|}
\hline Variable & $\begin{array}{l}\text { In(grave } \\
\text { price) }\end{array}$ & $\begin{array}{l}\text { In(house } \\
\text { price) }\end{array}$ & $\begin{array}{l}\text { In(personal } \\
\text { income) }\end{array}$ & $\begin{array}{c}\text { In(land } \\
\text { price) }\end{array}$ & $\begin{array}{c}\text { Urbanization } \\
\text { rate }\end{array}$ & $\begin{array}{c}\text { Population } \\
\text { density }\end{array}$ & $\begin{array}{c}\text { Population } \\
>65\end{array}$ & $\begin{array}{c}\text { Mortality } \\
\text { rate }\end{array}$ & $\begin{array}{c}\text { Cremation } \\
\text { rate }\end{array}$ & $\begin{array}{l}\text { Religious } \\
\text { affiliation }\end{array}$ & $\begin{array}{c}\text { Land } \\
\text { regulation } \\
\text { index }\end{array}$ \\
\hline $\begin{array}{l}\text { In(grave } \\
\text { price) }\end{array}$ & 1.0000 & & & & & & & & & & \\
\hline $\begin{array}{l}\ln (\text { house } \\
\text { price) }\end{array}$ & 0.3290 & 1.0000 & & & & & & & & & \\
\hline $\begin{array}{l}\ln (\text { personal } \\
\text { income) }\end{array}$ & 0.0241 & 0.6425 & 1.0000 & & & & & & & & \\
\hline In(land price) & 0.2193 & 0.8270 & 0.5179 & 1.0000 & & & & & & & \\
\hline $\begin{array}{l}\text { Urbanization } \\
\text { rate }\end{array}$ & 0.4856 & 0.6032 & 0.6329 & 0.5106 & 1.0000 & & & & & & \\
\hline $\begin{array}{l}\text { Population } \\
\text { density }\end{array}$ & -0.0695 & 0.5346 & 0.6493 & 0.4702 & 0.4823 & 1.0000 & & & & & \\
\hline $\begin{array}{l}\text { Population > } \\
65\end{array}$ & -0.3364 & -0.0932 & -0.0670 & -0.0201 & -0.2974 & 0.1057 & 1.0000 & & & & \\
\hline Mortality rate & -0.5491 & -0.1367 & -0.0621 & 0.0374 & -0.4036 & -0.1873 & 0.3824 & 1.0000 & & & \\
\hline $\begin{array}{l}\text { Cremation } \\
\text { rate }\end{array}$ & 0.1699 & 0.5029 & 0.2961 & 0.5148 & 0.4965 & -0.0399 & -0.0330 & -0.0115 & 1.0000 & & \\
\hline $\begin{array}{l}\text { Religious } \\
\text { affiliation }\end{array}$ & 0.0578 & -0.4710 & -0.2983 & -0.4959 & -0.3077 & -0.0987 & 0.0594 & -0.0091 & -0.7977 & 1.0000 & \\
\hline $\begin{array}{l}\text { Land } \\
\text { regulation } \\
\text { index }\end{array}$ & 0.1853 & 0.7765 & 0.5907 & 0.7701 & 0.5553 & 0.5277 & 0.0575 & -0.0316 & 0.6299 & -0.5577 & 1.0000 \\
\hline
\end{tabular}

Note: Religious affiliation is not available for Hawaii and Mississippi. 
This is the accepted version of an article published by Elsevier in Economic Modelling, Vol. 64, 638-645. Published version available from: https://doi.org/10.1016/i.econmod.2017.05.002 Accepted version made available from SOAS Research Online under CC-BY-NC-ND 4.0 International Licence from http://eprints.soas.ac.uk/24137/

Table 3. Grave prices: OLS regressions on individual data.

\begin{tabular}{|c|c|c|c|c|c|c|c|c|}
\hline $\begin{array}{l}\text { Dependent variable: } \\
\text { Grave price }\end{array}$ & (a) & (b) & (c) & (d) & (e) & (f) & (g) & (h) \\
\hline Ln(house price) & $\begin{array}{c}0.393 * * * \\
(0.059)\end{array}$ & - & $\begin{array}{l}0.569 * * * \\
(0.076)\end{array}$ & $\begin{array}{c}0.595 * * * \\
(0.082)\end{array}$ & $\begin{array}{c}0.588 * * * \\
(0.076)\end{array}$ & $\begin{array}{c}0.502 * * * \\
(0.050)\end{array}$ & $\begin{array}{c}1.466^{* * *} \\
(0.178)\end{array}$ & $\begin{array}{l}1.752 * * * \\
(0.221)\end{array}$ \\
\hline Ln(Personal income) & $(0.00)$ & $\begin{array}{c}0.250 \\
(0.154)\end{array}$ & $\begin{array}{c}-0.771 * * * \\
(0.185)\end{array}$ & $\begin{array}{c}-0.905 * * * \\
(0.121)\end{array}$ & $\begin{array}{c}-1.095 * * * \\
(0.211)\end{array}$ & $\begin{array}{c}-1.254 * * * \\
(0.211)\end{array}$ & $\begin{array}{c}-1.456 * * * \\
(0.289)\end{array}$ & $\begin{array}{c}-1.418 * * * \\
(0.319)\end{array}$ \\
\hline Ln(land price) & - & - & - & $\begin{array}{l}-0.053 \\
(0.033)\end{array}$ & $\begin{array}{l}-0.031 \\
(0.026)\end{array}$ & - & $\begin{array}{c}-0.169 * * * \\
(0.041)\end{array}$ & $\begin{array}{c}-0.239 * * * \\
(0.038)\end{array}$ \\
\hline Urbanization rate & - & - & - & $\begin{array}{c}0.746^{* * * *} \\
(0.148)\end{array}$ & $\begin{array}{c}1.046 * * * \\
(0.274)\end{array}$ & $\begin{array}{c}1.201 * * * \\
(0.343)\end{array}$ & $\begin{array}{c}0.362 \\
(0.392)\end{array}$ & - \\
\hline Cremation rate & - & - & - & - & $\begin{array}{l}-0.213 \\
(0.210)\end{array}$ & $\begin{array}{l}-0.414^{*} \\
(0.233)\end{array}$ & $\begin{array}{l}-0.257 \\
(0.254)\end{array}$ & - \\
\hline Religious affiliation & - & - & - & - & $\begin{array}{c}0.006 \\
(0.004)\end{array}$ & - & $\begin{array}{c}0.003 \\
(0.006)\end{array}$ & - \\
\hline Constant & $\begin{array}{c}2.577 * * * \\
(0.764)\end{array}$ & $\begin{array}{c}4.901 * * * \\
(1.623)\end{array}$ & $\begin{array}{c}8.447 * * * \\
(1.507)\end{array}$ & $\begin{array}{c}9.667 * * * \\
(1.417) \\
\end{array}$ & $\begin{array}{c}10.861 * * * \\
(2.072)\end{array}$ & $\begin{array}{l}13.724 * * * \\
(1.882)\end{array}$ & $\begin{array}{l}5.894^{*} \\
(3.430)\end{array}$ & $\begin{array}{c}3.043 \\
(2.399)\end{array}$ \\
\hline$R^{2}$ & 0.037 & 0.002 & 0.048 & 0.402 & 0.415 & 0.419 & - & - \\
\hline$F$ & 43.722 & 2.632 & 28.512 & 44.048 & 46.792 & 71.760 & $428.42^{+}$ & $66.82^{+}$ \\
\hline Prob $>F$ & 0.000 & 0.105 & 0.000 & 0.000 & 0.000 & 0.000 & 0.000 & 0.000 \\
\hline Root MSE & 0.613 & 0.624 & 0.610 & 0.178 & 0.175 & 0.177 & 0.222 & 0.257 \\
\hline Endogeneity & - & - & - & - & - & - & $56.865 * * *$ & $39.763 * * *$ \\
\hline Underidentification & - & - & - & - & - & - & $48.999 * * *$ & $25.496^{* * *}$ \\
\hline Weak identification & - & - & - & - & - & - & $61.936^{* * *}$ & $24.317 * * *$ \\
\hline Overidentification & - & - & - & - & - & - & $4.719^{* *}$ & 0.017 \\
\hline No. observations & 10,424 & 10,424 & 10,424 & 10,424 & 10,391 & 10.424 & 10,391 & 10,424 \\
\hline
\end{tabular}

Columns (a)-(f): OLS. Columns (g)-(h): IV; additional instruments: proportion of population aged 15-44, land regulation index. ${ }^{+}$Wald Chi-squared.

Endogeneity: Wooldridge (1995) $F$ score test. Underidentification: Kleibergen-Paap (2006) LM statistic. Weak identification: Kleibergen-Paap (2006) $r k$ Wald $F$ statistic.

Overidentification: Hansen $J$ statistic.

Standard errors clustered by city in brackets. Religious affiliation is not available for Hawaii and Mississippi in columns (e) and (g).

* significant at $10 \%$; ** significant at $5 \%$; ** significant at $1 \%$. 
This is the accepted version of an article published by Elsevier in Economic Modelling, Vol. 64, 638-645. Published version available from: https://doi.org/10.1016/i.econmod.2017.05.002 Accepted version made available from SOAS Research Online under CC-BY-NC-ND 4.0 International Licence from http://eprints.soas.ac.uk/24137/

Table 4. Grave prices by state: OLS regressions.

\begin{tabular}{|c|c|c|c|c|c|c|c|}
\hline Dependent variable: Grave price & (a) & (b) & (c) & (d) & (e) & (f) & (g) \\
\hline Ln(house price) & $\begin{array}{l}0.302 * \\
(0.154)\end{array}$ & - & $\begin{array}{c}0.490 * * * \\
(0.164)\end{array}$ & $\begin{array}{c}0.143 \\
(0.218)\end{array}$ & $\begin{array}{c}0.355^{* * *} \\
(0.158)\end{array}$ & $\begin{array}{l}2.304 * \\
(1.372)\end{array}$ & $\begin{array}{l}0.484^{*} \\
(0.262)\end{array}$ \\
\hline Ln(Personal income) & - & $\begin{array}{c}0.074 \\
(0.511)\end{array}$ & $\begin{array}{c}-0.975 \\
(0.675)\end{array}$ & $\begin{array}{c}-1.309 * * \\
(0.614)\end{array}$ & $\begin{array}{c}-1.610^{* *} \\
(0.635)\end{array}$ & $\begin{array}{c}-3.461^{* *} \\
(1.601)\end{array}$ & $\begin{array}{c}-1.793 * * * \\
(0.634)\end{array}$ \\
\hline Ln(land price) & - & - & - & $\begin{array}{c}0.028 \\
(0.059)\end{array}$ & - & $\begin{array}{c}-0.381 \\
(0.269)\end{array}$ & - \\
\hline Urbanization rate & - & - & - & $\begin{array}{c}1.325^{* * *} \\
(0.446)\end{array}$ & $\begin{array}{c}1.559 * * * \\
(0.454)\end{array}$ & $\begin{array}{l}1.365^{*} \\
(0.820)\end{array}$ & $\begin{array}{c}1.459 * * * \\
(0.492)\end{array}$ \\
\hline Mortality rate & - & - & - & $\begin{array}{c}-0.528 * * * \\
(0.161)\end{array}$ & $\begin{array}{c}-0.387 * * \\
(0.157)\end{array}$ & $\begin{array}{c}0.052 \\
(0.421)\end{array}$ & $\begin{array}{c}-0.385 * * * \\
(0.140)\end{array}$ \\
\hline Cremation rate & - & - & - & $\begin{array}{c}-0.156^{*} \\
(0.089)\end{array}$ & $\begin{array}{c}-0.184 * * \\
(0.085)\end{array}$ & $\begin{array}{l}-0.141 \\
(0.199)\end{array}$ & $\begin{array}{c}-0.203 * * \\
(0.089)\end{array}$ \\
\hline Religious affiliation & - & - & - & $\begin{array}{c}0.005 \\
(0.012)\end{array}$ & - & $\begin{array}{c}0.020 \\
(0.019)\end{array}$ & - \\
\hline Constant & $\begin{array}{l}3.727^{*} \\
(1.909)\end{array}$ & $\begin{array}{c}6.743 \\
(5.323)\end{array}$ & $\begin{array}{c}11.561 * \\
(5.911)\end{array}$ & $\begin{array}{c}17.917 * * * \\
(5.430)\end{array}$ & $\begin{array}{c}18.930 * * * \\
(5.681)\end{array}$ & $\begin{array}{c}16.095^{*} \\
(9.750)\end{array}$ & $\begin{array}{c}19.303 * * * \\
(5.401)\end{array}$ \\
\hline$R^{2}$ & 0.108 & 0.001 & 0.168 & 0.5671 & 0.558 & - & - \\
\hline $\boldsymbol{F}$ & 3.859 & 0.021 & 4.714 & 10.697 & 16.150 & $30.67^{+}$ & $66.62^{+}$ \\
\hline Prob $>F$ & 0.057 & 0.886 & 0.015 & 0.000 & 0.000 & 0.000 & 0.000 \\
\hline Root MSE & 0.361 & 0.382 & 0.354 & 0.267 & 0.269 & 0.447 & 0.250 \\
\hline Endogeneity & - & - & - & - & - & 2.889 & 0.320 \\
\hline Underidentification & - & - & - & - & - & 2.559 & $7.027 * * *$ \\
\hline Weak identification & - & - & - & - & - & 1.009 & $10.436^{* * *}$ \\
\hline Overidentification & - & - & - & - & - & 0.244 & $2.712^{*}$ \\
\hline No. observations & 39 & 39 & 39 & 37 & 39 & 37 & 39 \\
\hline
\end{tabular}

Columns (a)-(e): OLS. Column (f)-(g): IV; additional instruments: proportion of population aged 15-44, land regulation index. ${ }^{+}$Wald Chi-squared.

Endogeneity: Wooldridge (1995) $F$ score test. Underidentification: Kleibergen-Paap (2006) LM statistic. Weak identification: Kleibergen-Paap (2006) $r k$ Wald $F$ statistic.

Overidentification: Hansen $J$ statistic.

Notes: Heteroskedasticity-robust standard errors in brackets. Religious affiliation is not available for Hawaii and Mississippi in columns (d) and (f)

$*$ significant at $10 \% ; * *$ significant at $5 \% ; * *$ significant at $1 \%$. 
Table 5. Sensitivity analysis with respect to religious affiliation.

\begin{tabular}{|c|c|c|c|c|c|c|c|c|c|}
\hline & \multicolumn{4}{|c|}{ Fraction $U=1$ by outcome } & \multirow[t]{2}{*}{$d$} & \multirow[t]{2}{*}{$s$} & \multirow[t]{2}{*}{ ATT } & \multirow[t]{2}{*}{ Bias \% } & \multirow[t]{2}{*}{ SE } \\
\hline & $p_{11}$ & $p_{10}$ & $p_{01}$ & $p_{00}$ & & & & & \\
\hline $\begin{array}{l}\text { No } \\
\text { confounder }\end{array}$ & 0.0 & 0.0 & 0.0 & 0.0 & 0 & 0 & 0.066 & - & 0.246 \\
\hline $\begin{array}{l}\text { Calibrated } \\
\text { confounder: }\end{array}$ & & & & & & & & & \\
\hline (a) & 0.8 & 0.6 & 0.6 & 0.5 & 0.1 & 0.14 & 0.047 & 28.8 & 0.245 \\
\hline (b) & 0.8 & 0.6 & 0.7 & 0.5 & 0.2 & 0.08 & 0.031 & 53.0 & 0.234 \\
\hline (c) & 0.8 & 0.7 & 0.6 & 0.5 & 0.1 & 0.20 & 0.034 & 48.5 & 0.258 \\
\hline (d) & 0.9 & 0.6 & 0.6 & 0.5 & 0.1 & 0.19 & 0.011 & 83.3 & 0.243 \\
\hline
\end{tabular}

Note

$U=1$ if religious affiliation is greater than or equal to the median.

Bias $\%=100 \cdot($ ATT baseline - ATT $) /$ ATT baseline

SE: bootstrapped standard errors obtained with 100 replications

$d=p_{01}-p_{00}>0$

$s=p_{1}-p_{0} .>0$ 